\title{
Bend, Push, Stretch: Remarkable Structure and Mechanics of Single Intermediate Filaments and Meshworks
}

\author{
K. Tanuj Sapra ${ }^{1, *(D)}$ and Ohad Medalia ${ }^{2, *(D)}$ \\ 1 Department of Biosystems Science and Engineering, Eidgenössische Technische Hochschule (ETH) Zürich, \\ 4058 Basel, Switzerland \\ 2 Department of Biochemistry, University of Zurich, Winterthurerstrasse 190, 8057 Zurich, Switzerland \\ * Correspondence: tanuj.sapra@bsse.ethz.ch (K.T.S.); omedalia@bioc.uzh.ch (O.M.)
}

Citation: Sapra, K..T.; Medalia, O. Bend, Push, Stretch: Remarkable Structure and Mechanics of Single Intermediate Filaments and Meshworks. Cells 2021, 10, 1960. https://doi.org/10.3390/cells 10081960

Academic Editors: Rudolf E. Leube and Paolo Bernardi

Received: 14 June 2021

Accepted: 28 July 2021

Published: 2 August 2021

Publisher's Note: MDPI stays neutral with regard to jurisdictional claims in published maps and institutional affiliations.

Copyright: (c) 2021 by the authors. Licensee MDPI, Basel, Switzerland. This article is an open access article distributed under the terms and conditions of the Creative Commons Attribution (CC BY) license (https:// creativecommons.org/licenses/by/ $4.0 /)$.

\begin{abstract}
The cytoskeleton of the eukaryotic cell provides a structural and functional scaffold enabling biochemical and cellular functions. While actin and microtubules form the main framework of the cell, intermediate filament networks provide unique mechanical properties that increase the resilience of both the cytoplasm and the nucleus, thereby maintaining cellular function while under mechanical pressure. Intermediate filaments (IFs) are imperative to a plethora of regulatory and signaling functions in mechanotransduction. Mutations in all types of IF proteins are known to affect the architectural integrity and function of cellular processes, leading to debilitating diseases. The basic building block of all IFs are elongated $\alpha$-helical coiled-coils that assemble hierarchically into complex meshworks. A remarkable mechanical feature of IFs is the capability of coiled-coils to metamorphize into $\beta$-sheets under stress, making them one of the strongest and most resilient mechanical entities in nature. Here, we discuss structural and mechanical aspects of IFs with a focus on nuclear lamins and vimentin.
\end{abstract}

Keywords: lamin; vimentin; mechanobiology; cryo-electron tomography

\section{Introduction}

In the crowded intracellular environment, information passes across distances up to tens of micrometers. One way to achieve this is through biochemical signals that rely on diffusion; another, more familiar way, akin to the macroscopic world, is physical transport [1]. Molecular motors walk on macromolecular tracks made of protein filaments, transporting vesicles, proteins and molecules from the cell membrane to the inside of the nucleus. Microtubules ( $24 \mathrm{~nm}$ in diameter $)$ and actin filaments $(\sim 8 \mathrm{~nm}$ in diameter $)$ are examples of dynamic tracks that polymerize and depolymerize, enabling motor proteins to carry vesicular cargoes. Unlike microtubules and actin, intermediate filaments (IFs) are nonpolar structures, their assembly dynamics are nucleotide independent and they have no known transport function [2]. Cytoplasmic IFs assemble into $\sim 10 \mathrm{~nm}$ diameter structures; however, lamin filaments are now shown to be $\sim 3.5 \mathrm{~nm}$ [3].

IFs are the most versatile load-bearing entities found in nature that maintain the structural integrity of the cell and the nucleus [4]. Along with F-actin, IFs are key players in mechanotransduction [5]; mechanical wave propagation along the filaments is an ingenious engineering solution that cells have incorporated $[1,6]$. In simple words, the persistence length can be defined as the length of the polymer chain over which it stays rigid. As

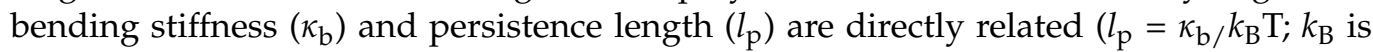
the Boltzmann's constant), out of the three cellular filaments, IFs are the most flexible with a $l_{\mathrm{p}} \sim 0.2-2 \mu \mathrm{m}$, while F-actin and microtubules are stiffer with a $l_{\mathrm{p}} \sim 10-20 \mu \mathrm{m}$ and a $l_{\mathrm{p}}>1 \mathrm{~mm}$, respectively $[3,7,8]$. Persistence length is also a key parameter in determining the strain-stiffening of polymers [9], an important property in forming robust structures. Measurements of persistence lengths and load-bearing capacity in vitro show that microtubules and F-actin break under piconewton $(\mathrm{pN})$ forces and do not absorb shocks. In 
contrast, IFs can be stretched to many times their original lengths and are able to resist failure even under nanoNewton $(\mathrm{nN})$ forces [10-13].

The biochemical and immunological identities of IFs along with their functional importance have been well documented for over four decades [14]. IFs are encoded by at least 70 genes and are grouped into six types (I-V, and orphan); the most commonly studied are keratins (types I and II), vimentin, desmin (type III), neurofilaments, nestin (type IV), lamins (type V), phakinin and filensin (orphan) [15]. Lamins are the only IFs that form the nuclear lamina, a shell-like meshwork abutting the inner nuclear membrane, and impart a structural and mechanical framework to the nucleus [16,17]. The cytoskeleton is connected to the nucleoskeleton-lamin meshwork-via LINC (linker of nucleoskeleton and cytoskeleton) complex proteins that traverse the double bilayer membrane of the nucleus creating a continuous network [18]. This molecular continuum is a functional necessity to convert mechanical signal input from the extracellular environment into genetic outputs inside the nucleus $[1,19,20]$. Thus, cytoskeletal and nucleoskeletal networks are physically fine-tuned to achieve the required cellular functions [21,22]. Mutations in any one filament type or associated proteins may perturb the delicate balance leading to debilitating diseases [8].

More than 110 distinct diseases are associated with IFs, affecting almost every organ in the human body (http:/ /www.interfil.org/, accessed on 1 August 2021) [23,24]. The diseases are caused by mutations in multiple cell types-lamins in nucleated cells, keratin in epithelial cells, vimentin in mesenchymal cells, neurofilaments in neurons, desmin in myocytes [25] and filensin and phakinin in lens [26]. Keratins and vimentin are also used as clinical markers for cancer [27-30], while vimentin is suggested to participate in SARS-CoV infection [31]. Lamins are known to be key to cancer progression, ageing and laminopathies [32,33]. Over 500 reported mutations in the lamin genes-some recently found in $L M N B$ [34] and many studied in $L M N A$-are implicated in multiple overlapping clinical phenotypes of four major disease types: striated muscle diseases, lipodystrophy syndromes, peripheral neuropathy and accelerated ageing disorders [35,36]. This group of diseases, termed laminopathies, is an important example of mutations affecting loadbearing tissues, such as striated muscles, potentially leading to mechanical failure. Due to their importance in cell physiology [37,38], great efforts have been focused on understanding the mechanical role of IFs.

\section{IFs Structure, Lamin Filaments and Network Organization}

Besides metazoan cells, IFs have been investigated structurally and mechanically in a number of invertebrate model systems including Caenorhabditis elegans (C. elegans) [39], Danio rerio [40], Xenopus laevis (X. leavis) [41] and, Drosophila melanogaster [42], enhancing our functional understanding of this important class of cytoskeletal proteins. In general, insights into the structure of IFs have been few and far between [43-45]. A few examples of successful attempts include vimentin and keratin filaments by cryo-EM [46-48] and X-ray structures of the 2B subdomain [49] and the $\alpha$-helical coiled-coil region of vimentin [50], the 2B subdomain of lamin A [51] and heteropolymeric keratins K5 and K14 [52]. Additional biophysical approaches were also utilized to resolve the structure of IF fragments, summarized in [53].

All IFs share a common tripartite domain structure comprising a highly conserved, centrally located $\alpha$-helical coiled-coil rod domain, capped by a flexible $\mathrm{N}$-terminal head domain and a flexible C-terminal tail domain. Lamin filaments are type V IFs, and therefore share the conserved tripartite structure with other IFs. In aqueous solution, lamins are constitutive dimers of $\alpha$-helices arranged to form a coiled-coil rod domain with an $\mathrm{N}$ terminal head domain (31 amino acids, aa) and a C-terminal tail (196 aa) that contains an Ig domain. Thus, the formed polymers are decorated with globular Ig domains along the filament with $\sim 20 \mathrm{~nm}$ spacing [3]. In mammals, the lamin meshwork mostly comprises four types of lamin isoforms-lamins A and C, and lamins B1 and B2 [54]. The first snapshots of the lamin meshwork were obtained in the early 1980s using platinum-shadowing electron 
microscopy showing the LIII filaments that constitute the majority of lamins in the X. laevis oocyte nucleus [41]. The images of fixed samples showed the lamin filaments arranged in an almost perfect orthogonal pattern without nuclear pore complexes (NPCs). Using field-emission scanning electron microscopy, a similar arrangement was observed later [55]. The diameter of a single lamin filament was refined to be $\sim 7 \mathrm{~nm}$ (estimated to be $3-4 \mathrm{~nm}$ without the chromium metal coat).

Obtaining structures with atomic details has been a daunting challenge for IFs in general, owing to their insoluble nature and a tendency to form paracrystalline assemblies in vitro [56]. A 'divide and conquer' strategy has employed truncated filament fragments for X-ray crystallography, electron paramagnetic resonance and electron microscopy, allowing the creation of atomic models of full-length filaments [45,57]. For the most part, IF models have proven useful; however, the accuracy of structures obtained by stitching together constituent parts, that may behave very differently in crystals without their native molecular contacts, has pushed for efforts to explore better techniques for obtaining native structures in situ or even in vivo. Recently, 3D-structured illumination microscopy (3D-SIM) in conjunction with image processing analysis provided a view of the lamin meshwork inside the mammalian nucleus [58,59].

Unprecedented advances in cryo-electron microscopy have unleashed an era of structural determination of macromolecules at atomic resolution $[60,61]$. Besides the resolution revolution in single particle imaging, in situ structural analysis by cryo-electron tomography (cryo-ET) provides the means to gain structural insights into intact cells [62] (Figure 1). Cryo-ET has been used to reveal the structural make-up of whole organisms, cells and cellular organelles, and cellular processes [63-66]. Initial cryo-ET images of ectopically expressed C. elegans lamin meshworks in X. laevis oocyte nuclei showed that 4-6 nm thick filaments formed varied geometries unlike the orthogonal patterns observed before [67]. In vitro, C. elegans lamins assemble into $10 \mathrm{~nm}$ thick filaments and form paracrystalline arrays [68]. However, the relevance of such assemblies in vivo is unclear. Nevertheless, paracrystals do offer an opportunity to study mutations. For example, in C. elegans, the Hutchinson-Gilford Progeria syndrome-causing mutation Q159K in coil 1B (E145K in lamin A) led to a different assembly of only two protofilaments instead of three or four as in the wild-type lamin [69]. Similarly, the mutation L535P in the tail domain (L530P in lamin A), associated with Emery-Dreifuss muscular dystrophy, led to abnormal paracrystal assembly. Cryo-ET snapshots have afforded a high-resolution comparison in wild-type and mutated paracrystalline assemblies [70].

In recent years, technical developments in cryo-focused ion beam (FIB) milling of cells in conjunction with cryo-ET have provided comprehensive insights into the structure and organization of protein complexes in vivo and in situ $[63,64]$. Insights into the molecular arrangement of lamins and NPCs in an intact mammalian nucleus were recently obtained by using ghost nuclei devoid of much of the chromatin [3] (Figure 1A). The approach allowed observation of the structural framework of the mammalian lamin meshwork and measurement of the basic physical dimensions of single lamin filaments. Surprisingly, the ancestor of all $\sim 10 \mathrm{~nm}$ thick IFs assemble into $\sim 3.5 \mathrm{~nm}$ thick filaments [71].

Recent studies suggest that anti-parallel coiled-coil dimers are the building blocks for further polymerization. The study used a bacterially expressed human lamin A/C fragment ( $\sim 38 \mathrm{~nm}$ long, full length is $\sim 54 \mathrm{~nm}$ ) where high-resolution $X$-ray structure and cross-linking mass spectrometry analysis were utilized [72,73]. Thus, current knowledge suggests that lamin assembly is initiated by polypeptide dimerization through $\alpha$-helical coiled-coils to form staggered head-to-tail polar filaments [74,75]. The staggered filaments interact laterally to form tetrameric protofilaments, and finally interconnect to form the lamin meshwork [3,76]. 
A

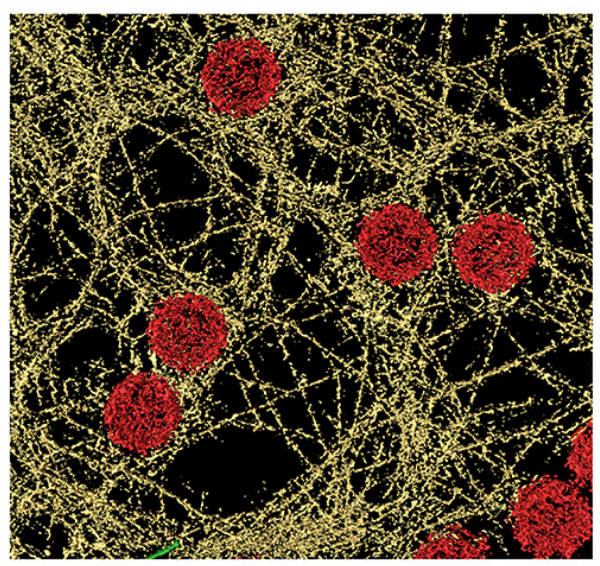

C

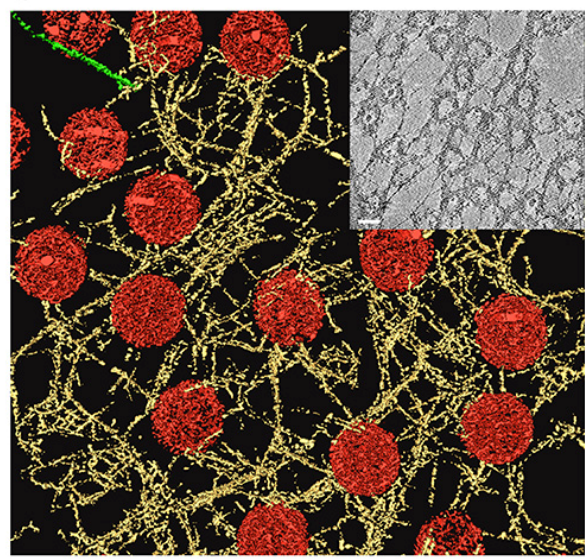

B

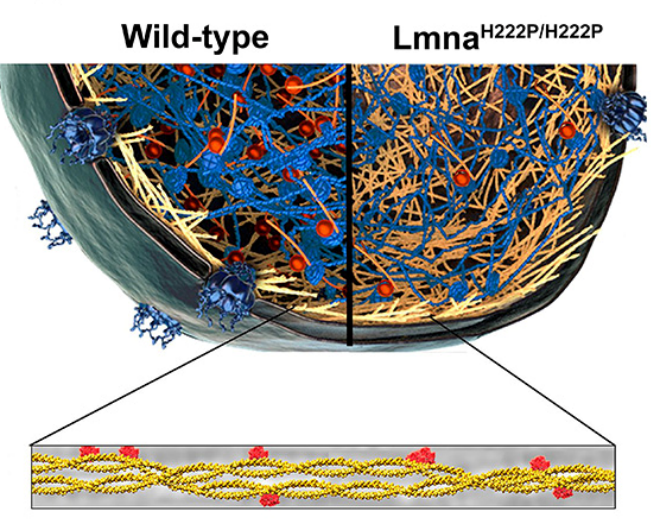

D

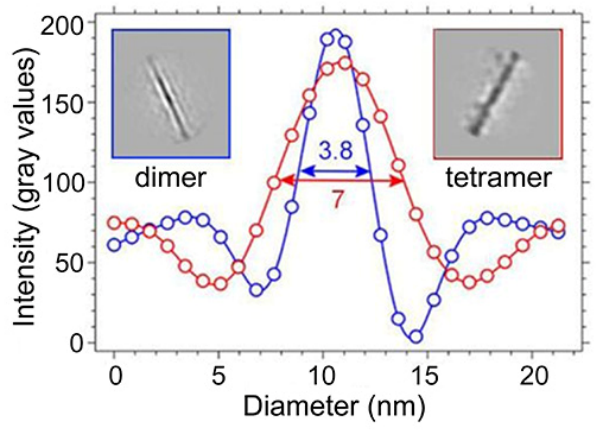

Figure 1. Molecular assembly of nuclear lamina and structure of a lamin filament. (A) Surface rendered view of a cryo-electron tomogram of mouse embryonic fibroblast nucleus. Nuclear lamins formed a 3D meshwork of filaments (yellow) connected to the nuclear pore complexes (NPCs, red). Actin filament is shown in green. Field of view, $700 \mathrm{~nm} \times 700 \mathrm{~nm}$ [1]. (B) A model showing the wild-type nuclear lamina (lamin filaments in yellow) connected to chromatin (blue) and chromatin binding factors (red), and the changes in mutant $\left(\mathrm{Lmna}^{\mathrm{H} 222 \mathrm{P} / \mathrm{H} 222 \mathrm{P}}\right)$ mouse embryonic fibroblasts where lamin meshwork is more exposed. A lamin filament tetramer comprised of two $\alpha$-helical coiled-coils with Ig domains (red); figure adapted from [2]. (C) Surface rendered view of a cryoelectron tomogram acquired on a spread nuclear envelope of the X. laevis oocyte. Inset, a $10 \mathrm{~nm}$ slice through a tomogram of spread NE showing the nuclear lamina of X. laevis oocyte; scale bar $100 \mathrm{~nm}$ [3]. (D) Density of the rod-like structures from cryo-electron tomograms of two structural class-averages (framed blue and red) indicating filament thickness of $\sim 3.8 \mathrm{~nm}$ and $\sim 7 \mathrm{~nm}$ in agreement with a tetramer and lateral association of tetramers, respectively; figure adapted from [3].

Labeling lamins with colloidal gold nanoparticles $(6 \mathrm{~nm}$ and $10 \mathrm{~nm})$ showed that lamin A/C and lamin B1 filaments exist in segregated domains [3]. Analysis of fluorescence images obtained by stochastic optical reconstruction microscopy (STORM) has suggested that lamin A and lamin B meshworks are concentric; lamin B is anchored to the inner nuclear membrane via a farnesyl moiety and the lamin A meshwork is perched on it [77]. It remains to be verified if the differences in localization are independent of sample preparation which included detergent and chemical fixation procedures. Nevertheless, arrangement of the two segregated meshworks may have far reaching implications in diseases where blebbing is a commonly observed phenotype [78,79]. Recent cryo-ET findings suggest that mutations in $L M N A$ ( $\mathrm{Lmna}^{\mathrm{H} 222 \mathrm{P} / \mathrm{H} 222 \mathrm{P}}$ ) in mouse embryonic fibroblasts perturb the meshwork organization [76] (Figure 1B). The mutation has been shown to cause mechanical aberrations, i.e., increased stiffness, of muscle cells [80]. 


\section{In Situ Mechanical Probing of IF Networks in Cells and Nuclei}

Owing to their mechanical roles in the cytoplasm and the nucleus, IFs have been the focus of intense mechanical investigations [81,82]. As in structural studies, X. laevis oocyte nuclei proved instrumental for mechanical studies of nuclear lamins. Ectopically expressed lamin A in X. laevis oocyte nuclei forms a distinct thick layer (30-100 nm) on top of the endogenous lamin LIII meshwork [83]. Mechanical studies with the atomic force microscope (AFM) measured the stiffness values of oocyte nuclei that increased from $\sim 1-2 \mathrm{mN} / \mathrm{m}$ (control without lamin A) to $\sim 5-7 \mathrm{mN} / \mathrm{m}$ (ectopically expressed lamin A). The stiffness increase was dependent on the expression level of lamin $\mathrm{A}$ as the nucleoplasm of X. laevis oocyte nucleus is suggested to be soft. Measurements on isolated nuclei using micropipette aspiration converged to a value of $25 \mathrm{mN} / \mathrm{m}$ for the elastic modulus of the lamin network [16]. The E145K mutation in lamin A, known to cause HutchinsonGilford progeria syndrome (HGPS) [84], leads to abnormal clustering of centrosomes, mis-localization of telomeres and perturbs the lamin network as indicated by lobulated nuclei [70]. Similar to wild-type lamin A, the E145K mutation containing lamin A expressed in X. laevis oocyte nuclei assembled as $100 \mathrm{~nm}$ thick multi-layered sheets on top of the endogenous lamin LIII meshwork [85]. AFM stiffness measurements of the E145K-lamin A-expressing nuclei indicated values of $\sim 5-9 \mathrm{mN} / \mathrm{m}$, similar to wild-type lamin A, but higher than lamin LIII. A more striking difference was observed in the Young's moduli of lamin A ( 40-80 MPa) and E145K-lamin A ( 100-340 MPa) [85].

Direct evidence for lamin alteration by the E145K-lamin A mutation came from mechanical measurements of isolated nuclei of human dermal fibroblasts [86]. A comparison of the nuclei of a 4-year-old progeria patient (E145K-lamin A) and two healthy donors of 10 and 61 years of age showed a clear increase in stiffness for progeria-expressing nuclei $(800 \mu \mathrm{N} / \mathrm{m})$ and the aged donor nuclei $(600 \mu \mathrm{N} / \mathrm{m})$, as compared to the young donor nuclei $(300 \mu \mathrm{N} / \mathrm{m})$. Interestingly, intact fibroblasts from the three donors showed no clear difference in nuclear stiffness, presumably due to the sensitivity limitations imposed by the cantilever that could not detect differences in nuclei surrounded by a buffering cushion of the cytoplasm, the cytoskeletal network and the cell membrane.

Recently, an in situ correlative approach was devised to study nuclear mechanics using AFM and confocal microscopy. A sharpened AFM cantilever tip was inserted into the cell nucleus through the plasma and the nuclear membranes at forces $>5 \mathrm{nN}$ [87]. Force-extension (FE) curves (a plot of deformation/extension of an object under force) and confocal microscopy images enabled a correlation of the breaching of the cell and nuclear membranes and pushing of the lamina. FE profiles clearly showed points when the cell membrane and the nuclear membrane were breached. The Young's modulus of isolated nuclei $(\sim 9 \mathrm{kPa})$ was three-fold lower than that of nuclei within the cell $(\sim 27 \mathrm{kPa})$. The difference may owe its origin to the exposure of the nucleus to intracellular balancing forces in vivo, a cornerstone of the tensegrity model [88]. Such new methods may also find applications in medical diagnostics. For example, comparing the Young's moduli of two bladder cancer cell lines showed that the isolated nuclei from low metastatic cells were stiffer $(\sim 8 \mathrm{kPa})$ than those from the high metastatic cells $(\sim 6 \mathrm{kPa})$. The same trend was observed for intact cells. A possible explanation forwarded was the difference in the lamina composition and lamin A concentration that imparts stiffness to the nucleus [87]. Studies utilizing spherical AFM tips gave a Young's modulus of $0.4 \mathrm{kPa}$ in mouse embryonic fibroblasts (when measured on top of the nucleus) [89]. The discrepancy in values is not surprising as force measurements depend on numerous factors, such as the cell type, passage number, cantilever tip geometry, contact area between the tip and the sample surface and the speed of the tip, to name a few [90]. As the contributions of other cellular components are difficult to separate in such studies, minimal systems are required to rule out effects arising from the nucleoplasm, nuclear membrane and chromatin. In vitro measurements of assembled filaments, or direct measurements of the meshwork and filaments in situ are required to unravel the mechanics of IFs in the absence of other cellular influences. 
Other IFs, such as keratins, are important mechanical building blocks of numerous biological structures in a variety of cell types and tissues [91]. The keratinocyte is an important cellular model system for studying the role of keratins in epithelial tissues. Pushing an AFM cantilever on keratinocytes and manipulating superparamagnetic beads inside a cell by magnetic tweezers showed that deleting type I or type II keratins leads to cell softening. The Young's modulus decreased to $412 \mathrm{~Pa}$ from $752 \mathrm{~Pa}$ in wild-type cells, and the cytoplasmic viscosity was reduced by $>40 \%$ in keratin-deficient cells. [92]. Stiffness recovery was achieved upon re-expressing the K14 and K5 keratins in type I and type II keratin-deficient cells, respectively. Similarly, a 60\% increase in cell deformability was observed by non-contact measurements in a microfluidic optical stretcher with a dualbeam laser trap [93]. Interestingly, the K14 keratin cytoskeleton is deformed less when keratinocytes are on stiff substrates (70 and $214 \mathrm{kPa})$ compared to a soft one $(8 \mathrm{kPa})$. The Young's modulus (stiffness) showed a progressive increase with substrate stiffness [94]. Similarly, Young's moduli of cells with and without vimentin also depend on substrate stiffness [95]. Substrate-dependent changes in the stiffness of nucleus correlated to up- and down-regulation of lamin A and lamin B have also been observed [96].

\section{In Vitro Single-Molecule Mechanical Characterization of IFs}

IF mechanical properties have been characterized using various techniques which measure the 'bulk' properties of network gels [7]. Micro-rheology, in particular, has given a foundation to understand the mechanical response of IF networks [97,98], and the physical origin of strain-stiffening under shear stress $[9,99]$. Under low stress, the polymers exhibit reversible linear entropic stretching. As the polymers are stretched, the chains undergo irreversible enthalpic unfolding resulting in nonlinear strain stiffening [100]. Our understanding of the mechanical properties of IFs and their physical origin has reached a consensus; however, the specific properties of different IFs remain an active area of investigation.

The first experimental proof that IFs are flexible and extensible came from stretching hagfish slime threads comprising keratin-like filaments using a home-built device [101]. The bundles were found to retain elasticity up to strains of $34 \%$, were capable of extending 2.2-fold, and exhibited a high tensile strength of $180 \mathrm{MPa}$ and toughness of $130 \mathrm{MJ} / \mathrm{m}^{3}$. In the same study, $\alpha$-helix to $\beta$-sheet transition of the filaments was reported based on $X$-ray diffraction and congo-red staining experiments. Single-molecule stretching of IFs was tested by AFM measurements of recombinant murine desmin [11,102], recombinant keratin and rat brain neurofilaments [11] and vimentin [103,104]. In these early studies, filaments adsorbed onto a surface were dragged by an AFM cantilever applying forces of 30-40 $\mathrm{nN}$ resulting in stretching of IFs up to 4.5-fold before breaking.

Desmin, a type III IF, physically connects successive sarcomeres and adjacent myofibrils in muscle cells. Their structural role exposes desmin filaments to repetitive extension and contraction, making them attractive targets for mechanical characterization. In vitro, desmin filaments are able to withstand forces up to $3.5 \mathrm{nN}$, possess a tensile strength of $240 \mathrm{MPa}$, dissipate mechanical energy $\left(50 \mathrm{MJ} / \mathrm{m}^{3}\right)$ and achieve strain hardening above $50 \%$ extension, reaching up to $240 \%$ [102]. Vimentin, another type III IF, assembles into a dense network in cells of mesenchymal origin. This network spans much of the cytoplasm, from the cell membrane to the outer nuclear membrane where they connect to the LINC complex, and therefore to the lamin meshwork [105]. The vimentin filament network forms a protective cage around the nucleus, conferring mechanical stability during migration through micrometer-sized pores [89]. The nanometer tip of the AFM cantilever was used to push single recombinantly expressed vimentin filaments freely suspended over a porous alumina membrane and record the filament extension. A Young's modulus of 300-400 MPa was determined presuming axial sliding between subunits. The modulus increased to $900 \mathrm{MPa}$ when the filaments were stabilized with glutaraldehyde, preventing sliding but permitting bending [103]. These results are in agreement with molecular dynamics 
(MD) simulations of stretching vimentin dimers that estimate a Young's modulus value of 380-540 MPa [106].

\section{Behavior of Single Vimentin Filaments at Controlled Force}

Albeit surface effects are difficult to rule out, in vitro AFM studies have provided relevant mechanistic insights into IF mechanical properties [104]. Like AFM, laser optical trapping (LOT) provides a sensitive approach to measure the forces required to stretch filaments that are anchored between micrometer-sized beads, held by lasers acting as soft springs [107,108] (Figure 2A). A force of $\sim 600 \mathrm{pN}$ was measured to stretch single, in vitro assembled vimentin filaments up to a strain of $\sim 125 \%$ along the long axis (Figure $2 B, C$ ). Similar to MD simulations [106], three clear regimes were observed in the FE profile: (i) an initial linear increase reaching a force of $\sim 300 \mathrm{pN}$ denoting the elastic response of the $\alpha$-helical coiled-coil at a strain of $\sim 10 \%$; (ii) a plateau where the $\alpha$-helical coiled-coils unfold and begin to transition to $\beta$-sheets; (iii) another linear rise that signifies stiffening at strains $>100 \%$. Interestingly, at low speeds, single vimentin filaments behaved as a soft material capable of extending up to a strain of $125 \%$. As the stretching speed was increased, the stiffening occurred faster and the filaments were extended only 75\% [108]. This behavior may reflect different states of the vimentin dimers comprising the tetrameric filament used in the experiments. Nevertheless, a two-state model was invoked to capture the $\alpha$-helix to $\beta$-sheet transition of the dimers during filament stretching (Figure 2D).
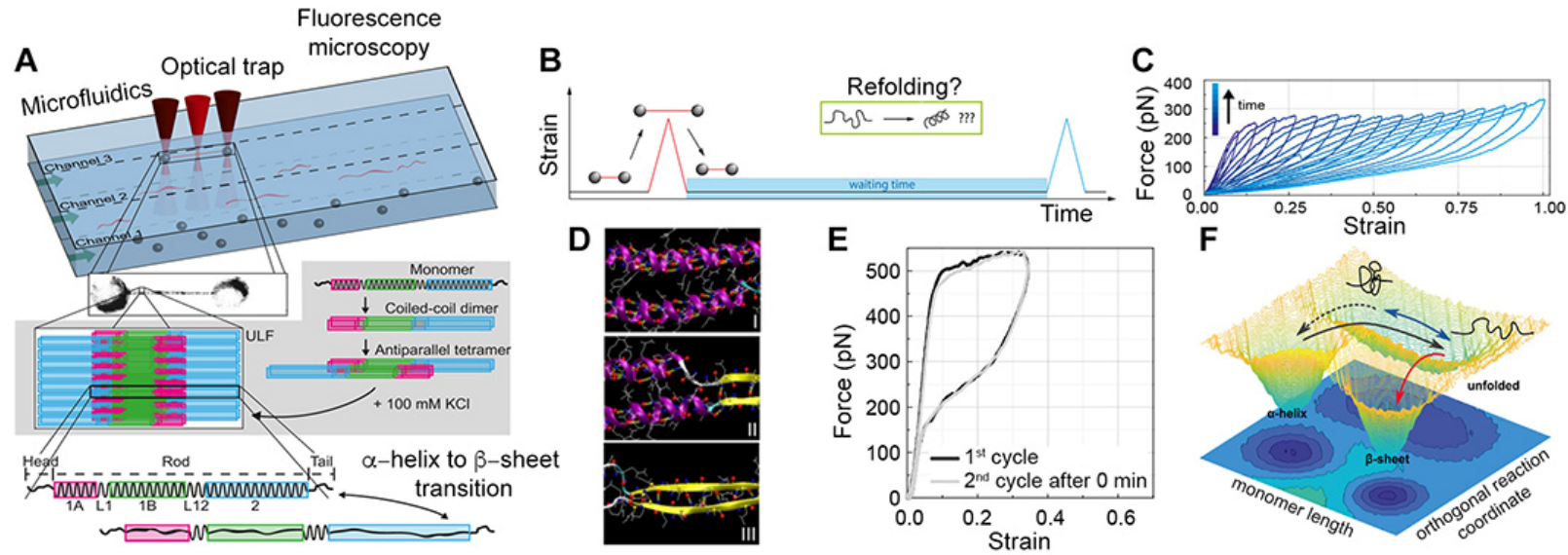

Figure 2. Stretching vimentin filaments in vitro. (A) Top, set-up combining microfluidics and laser optical traps for stretching single vimentin filaments. Single vimentin filaments flowing through microfluidic channels were captured and attached to micrometer-sized beads held in optical traps (shown in grey scale zoom). Middle, the assembly of vimentin is shown starting from a monomer to the unit length filament. Bottom, $\alpha$-helical coiled-coil transitions to a $\beta$-sheet under applied strain; figure adapted from [4]. (B,C) Experiment protocol showing stretching, waiting and refolding of single vimentin filaments. Repeated stretching and relaxation of a vimentin filament to increasing lengths showed progressive softening without refolding of the structure. (D) Molecular dynamic simulation snapshots of $\alpha$-helical to $\beta$-sheet transformation during vimentin stretching. I, II and III denote the $\alpha$-helical coiled-coil, unfolding and conversion to $\beta$-sheets, respectively; figure adapted from [5]. (E) Chemical cross-linking of vimentin by glutaraldehyde permitted filament refolding apparently to its initial state [6]. (F) A three-state model captures the unfolding and $\alpha$-helix to $\beta$-sheet transition of vimentin through an intermediate state. Refolding is only possible from the $\alpha$-helical unfolded state. Once the $\beta$-sheet is in the energy well, there is no going back to the $\alpha$-helical state. (B,C,E,F) reprinted with permission from [6]. Copyright 2019 American Chemical Society.

A single vimentin filament is a shock absorber capable of dissipating $70-80 \%$ of the input energy [109]. However, this property changes as single filaments become softer with every stretching cycle. The physical origin of this behavior may arise from the unfolding of a few $\alpha$-helical coiled-coils while others may still be folded. As more coiledcoils are unfolded with repeated stretching, the filaments may progressively soften. This model also captures the observation that the $\alpha$-helical coiled-coil domains of vimentin 
filaments do not unfold reversibly when stretched at low forces even if allowed to rest for up to an hour $[109,110]$. Interestingly, chemical cross-linking of the filaments with paraformaldehyde and glutaraldehyde made the $\alpha$-helix unfolding reversible even when no time is allowed between stretching-relaxation cycles. The potential barrier also widened from $0.17 \mathrm{~nm}$ for native vimentin to $1.2 \mathrm{~nm}$ for glutaraldehyde-treated vimentin, indicating that the molecular mechanism of $\alpha$-helix unfolding leading to $\beta$-sheet formation is different in the two cases. One proposed mechanism is, that in a chemically cross-linked filament, parallel helices unfold together, whereas in an untreated filament, the stochastic unfolding of an $\alpha$-helix destabilizes the parallel helices [109]. Cross-linking the polypeptides in a filament bypasses the intermediate state and the filaments are capable of recuperating to their original stiffness. The two-state model was aptly revised to a three-state model by introducing an intermediate state en route to the $\beta$-sheet from the $\alpha$-helix state (Figure $2 \mathrm{E}, \mathrm{F}$ ). Based on these results, it has been suggested that once unfolded, vimentin is incapable of functioning properly and may require repair mechanisms such as subunit exchange or reassembly processes [110]. Whether the filaments respond to forces in the same way when part of the intricate intracellular cytoskeletal network remains to be investigated. Surprisingly, the mechanical properties of single lamin filaments were shown to depend on the lamin meshwork topology or connectivity (discussed below) [111].

To capture the full mechanical response of vimentin filaments exceeding forces of $800 \mathrm{pN}$, AFM was used to pull putative single filaments from a mica surface using a cantilever tip [108]. At low forces ( $600 \mathrm{pN})$, FE profiles similar to optical tweezers were measured. Beyond this, the plateau reached up to $200 \%$ extension and a steep linear rise in force up to an extension of $300 \%$ was measured. The load-bearing capacity of vimentin filaments without breaking was measured to be at least $8 \mathrm{nN}$. Similar to vimentin, when single keratin filaments are stretched between $0.3 \mu \mathrm{m} / \mathrm{s}$ and $2.5 \mu \mathrm{m} / \mathrm{s}$, LOT shows an FE profile with an initial elastic regime at low strains, followed by a plateau for strains between $20 \%$ and $80 \%$, and a further steep rise up to $800 \mathrm{pN}$ leading to filament stiffening [112].

The structural differences between the major cytoskeletal filaments allow a cell to respond to force signals. Ion concentration, $\mathrm{pH}$ and post-translational modifications provide another mechanism to fine-tune the mechanical response of the filaments. For example, the mechanical responses of both keratin and vimentin filaments change drastically at a high ion concentration (100 $\mathrm{mM} \mathrm{KCl}$ ); keratin responds monotonically to an increasing strain whereas vimentin shows a nonlinear response with three clear regimes. Moreover, $~ 50 \%$ higher energy is required to stretch vimentin compared to keratin in high ion medium. The change in response has been explained by a difference in the negative charge per unit length of the two proteins. Vimentin carrying a higher charge (19 $\mathrm{e} / \mathrm{monomer})$ compared to keratin (8.5 $\mathrm{e} /$ monomer) requires more energy for stretching due to increased charge screening at high ion concentration. Concurrently, in vitro rheological measurements on vimentin networks showed that divalent ions, such as $\mathrm{Ca}^{2+}$ and $\mathrm{Mg}^{2+}$, tend to cross-link the filaments and increase their stiffness $[113,114]$. Truncation experiments suggested that the cross-linking is most likely mediated by the last 11 amino acids of the carboxy-terminal tail domain. Interestingly, the tail domain carries four negatively charged residues and two histidines. Ion concentration and also $\mathrm{pH}$ may fine-tune the delicate interplay between the complex IF networks in the cell in response to the barrage of forces [115].

Phosphorylation of IFs has a key role in cell division, migration, adhesion, cell differentiation and cell death [116]. The mechanical response to the stretching of vimentin filaments partially phosphorylated by protein kinase A was recently investigated in an optical trap [117]. Increasing phosphorylation $(1 \%, 5 \%, 10 \%)$ made the filaments softer as observed in the FE profile and denoted by the Young's moduli. The softening is owed to the negative charges introduced by phosphorylation that weaken the inter-dimer coupling mediated by the positive charges on the head domain. Binding of the regulatory protein 14-3-3 to the phosphorylated filament further softened the filament. Although the exact implications are not clear yet, this result may suggest a role in assembly-disassembly 
of the filaments, cell migration and metastasis $[118,119]$. Phosphorylation effects on the mechanical properties of lamin [120] and keratin [121] require further investigations.

\section{Interrogating Single Lamin Filaments In Vitro, In Silico and In Situ}

Membranes of nuclei hosting mutant lamins or devoid of lamins are prone to frequent ruptures, resulting in DNA damage during cell migration through confined spaces $(<20 \mu \mathrm{m})$ [122-125]. Nuclear mechanics and its most important determinant-laminshave therefore been studied for many years. Techniques such as micropipette aspiration and stretchable substrates give information on deformation characteristics of the lamin meshwork in the whole nucleus [126,127] and in the context of the whole cell [128], respectively. Compared to other IFs, in vitro mechanical characterization of single lamin filaments is lagging due to difficulties in expressing native-like filaments and their tendency to form paracrystalline assemblies. Lamin paracrystals most likely represent kinetic intermediates on the energy landscape and not native functional forms. The mechanical properties of filaments in paracrystals could be wildly different from those in vivo, where lamin dimers form thin filaments and a mesh-like network [54,129]. Nevertheless, paracrystalline assemblies provide an alternative approach to decipher the biophysical properties of lamins $[12,130]$.

The majority of the mutations specific to lamin A cause debilitating diseases [131]. While there has been no success in obtaining the complete lamin A filament in the soluble form, its rod domains, $1 \mathrm{~B}$ and $2 \mathrm{~B}$, have been expressed individually. AFM single-molecule force spectroscopy (SMFS) of these mini-lamin-forming domains provided insight into their roles in the elasticity of the lamin meshwork [132]. The average unfolding forces of domains $1 \mathrm{~B}$ and $2 \mathrm{~B}$ were $\sim 70 \mathrm{pN}$ and $\sim 80 \mathrm{pN}$, respectively. Rod domain $1 \mathrm{~B}$ was found to be a key player in meshwork formation and the major load-bearer, resisting strains up to $200 \%$ compared to $100 \%$ by domain $2 \mathrm{~B}$. A network of full-length lamin filaments is capable of withstanding strains up to $500 \%$, suggesting that the response to force is an emergent property of the lamin meshwork [111]. In vitro studies as described above for vimentin are required on full-length or components of lamins for a holistic view inside the nucleus. As shown for vimentin filaments that soften upon binding of 14-3-3, the effects of Lap $2 \alpha$, Lap $2 \beta$ and lamin B binding protein on lamin mechanical properties are also worth investigating.

As in studies of vimentin, in silico efforts have bridged the gap in knowledge between the mechanical behavior of single lamin dimers [133] and in a meshwork [134]. Molecular snapshots of simulated stretching showed that the $\alpha$-helical coiled-coils unfold at low forces (a few hundred $\mathrm{pN}$ ), before a structural transition of $\alpha$-helix to $\beta$-sheet, leading to stiffening at a high force (a few $\mathrm{nN}$ ). Finally, $\beta$-sheets undergo a stick-slip mechanism leading to a breakdown of the filament at $\sim 6 \mathrm{nN}$. Cell migration, division and diseases expose the lamin meshwork to continuous stretching and pushing forces in vivo [135,136]. Network models based on cryo-ET data were created and the pushing of lamin filaments in the models was simulated to garner molecular insights. Corroborating the in-plane stretching of lamin filaments [134], pushing lamin filaments orthogonal to the meshwork showed unfolding of the $\alpha$-helical coiled-coil domain at low forces, $\alpha$-helix to $\beta$-sheet transition and stiffening at high forces, and finally filament failure [111].

Direct measurements of lamins-in vitro or in situ - have been lagging owing to technical challenges; for example, expressing and assembling native filaments in vitro and measuring single filaments in situ using sensitive tools $[87,137,138]$. Recently, an integrative in situ approach was employed by combining AFM, cryo-ET and MD simulations to understand the design principles of the lamin meshwork in the nuclei of two metazoan classes-Amphibia and Mammalia [111]. Owing to its large size $(\sim 400 \mu \mathrm{m})$ compared to the mammalian nucleus $(\sim 20 \mu \mathrm{m})$, the $X$. laevis oocyte nucleus was chosen to mechanically characterize lamin filaments. This was the first time lamin filaments were characterized in close-to-native conditions, i.e., in its meshwork attached to the inner nuclear membrane in physiological buffer conditions (Figure 3A). The tip of the AFM cantilever was positioned 
at random positions on lamin filaments and pushed at a constant velocity to determine the force tolerance of single filaments. The similarities in the experimental and simulated FE profiles and the failure forces suggested that the molecular mechanisms were most likely the same (Figure 3B,C). As in the simulated FE profile, lamin filaments exhibited a nonlinear stretching behavior: at a low pushing force $(\leq 0.5 \mathrm{nN})$, the filaments showed reversible unfolding of $\alpha$-helical coiled-coils, and as the force increased, stiffening of filaments attributed to $\alpha$-helix to $\beta$-sheet transition was observed (Figure 3D). For comparison, reversible stretching of recombinant vimentin filaments has been observed up to a pushing force of $0.13 \mathrm{nN}$ [103] and more recently for chemically cross-linked vimentin [110].
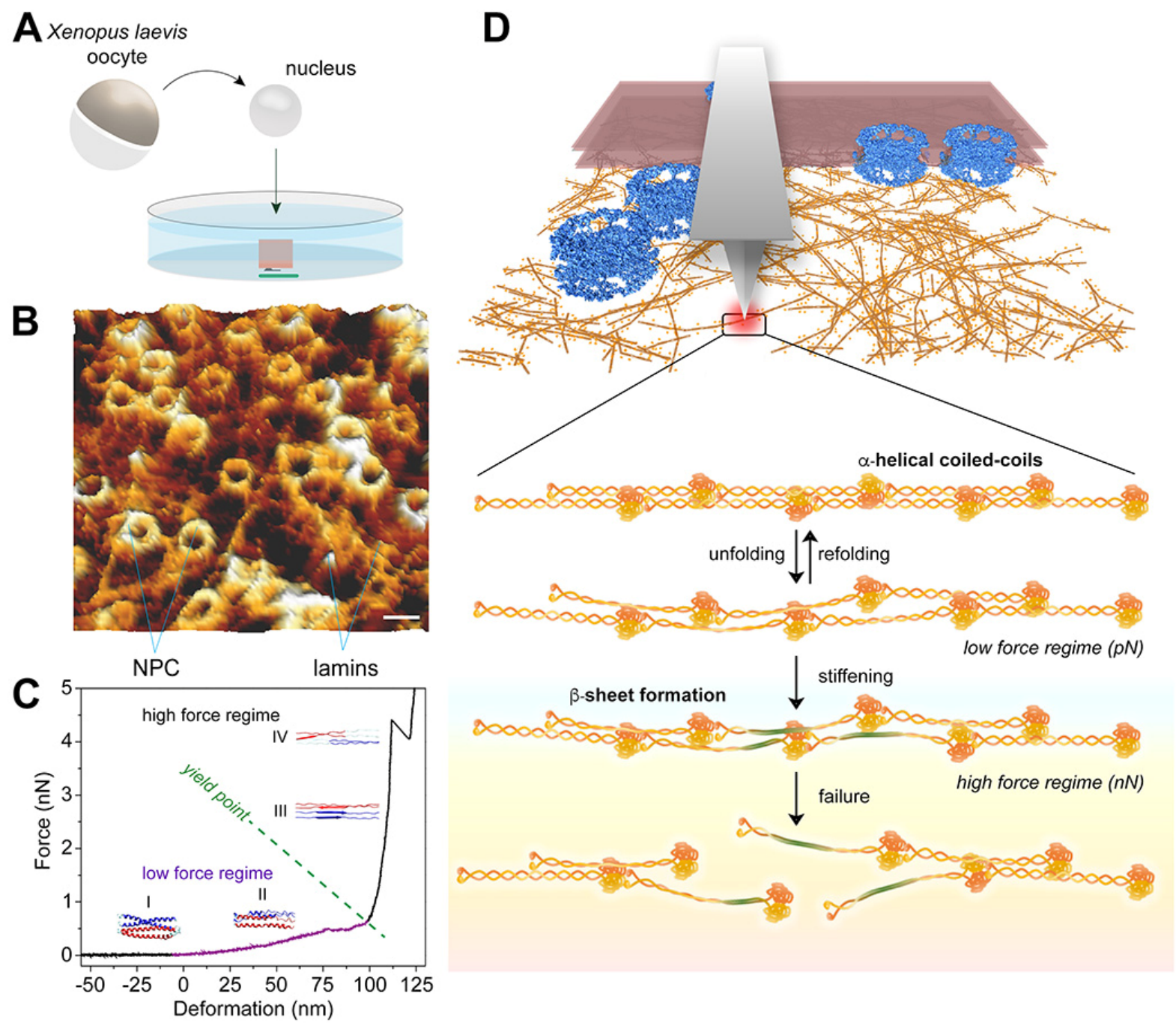

Figure 3. Mechanical characterization of lamin filaments in native meshwork. (A) Schematic illustration of the experimental set-up. Nuclei isolated from X. laevis oocytes were attached onto a poly-L-lysine-coated glass dish, and dissected to remove the chromatin and image the nuclear lamina [3]. (B) High-resolution AFM image of the nuclear lamina from the nucleoplasmic side showing areas of orthogonally arranged lamin filaments interspersed with NPCs; scale bar $100 \mathrm{~nm}$. (C) A typical force-extension (FE) signal showing the nonlinear behavior of a lamin filament in the meshwork. A single lamin filament in the meshwork when subjected to mechanical push showed a low force regime and a steep rise leading to failure of the lamin filament. The different regions were assigned to the molecular changes in the lamin $\alpha$-helical coiledcoils: I and II denote coiled-coil unfolding, III denotes $\alpha$-helix to $\beta$-sheet transition, and IV denotes the failure of $\beta$-sheets. The yield point denotes the point of plastic or permanent deformation, i.e., irreversible structural change. (D) Schematic model showing the response of lamin filaments when subjected to different levels of external force in vivo [1,3]. Figures adapted from $[2,3]$. 
When subjected to continuously increasing forces up to $5 \mathrm{nN}$, lamin filaments deformed to $\sim 90 \mathrm{~nm}$ before failing in steps of $4 \mathrm{~nm}$ and $8 \mathrm{~nm}$. Force-clamp experiments, where single filaments in a meshwork were subjected to a constant force $(0.75-3 \mathrm{nN})$, showed that the filaments mainly failed in discrete steps of 1,4 and $8 \mathrm{~nm}$ [111]. A continuous increase in the stiffness values was observed; the $\alpha$-helical coiled-coils are soft with a stiffness of $0.008 \mathrm{~N} / \mathrm{m}$ and $\beta$-sheets are stiff with values $>0.3 \mathrm{nN} / \mathrm{nm}$. Desmin filaments have a comparable initial stiffness of $0.006-1.2 \mathrm{~N} / \mathrm{m}$ [102]. The broad distributions in force and stiffness observed for lamins in situ could be due to the varied mechanical strength of the filament crosslinks in the anisotropic meshwork [139]. It is possible that the failure force of a lamin filament depends on its location in the meshwork and the position where it is loaded, i.e., close to a connecting node or away from it. The physical origin of this phenomenon is also reflected in a purely homogenous meshwork, such as a defect-free graphene lattice where the force distribution is very narrow [140]. Similarly, forces required to break single threads in a spider's web also depend on the type of the thread and the structure of the web [141].

Absorbing shocks is proposed to be a key function of IFs [16,109]. The $\alpha$-helical coiled-coil domain of lamin filaments unfolds reversibly up to a strain of $120 \%$ absorbing $\sim 10^{-17}$ J. Pulling collagen molecules adsorbed on a glass surface or directly from the bone femur resulted in the breaking of 'sacrificial' bonds in the sub-nanoN range. The energy of dissipation of such sacrificial bonds was measured to be $\sim 10^{-17} \mathrm{~J}$ [142]. Similar to collagen, lamin and other IFs may have evolved protective mechanisms whereby $\alpha$-helix unfolding absorbs energies in the mechanical range (up to $500 \mathrm{pN}$ ) that most physiological processes operate. The energy absorbed increases to $\sim 10^{-16} \mathrm{~J}$ during the entire unfolding, stiffening and failure of a lamin filament [111]. This is noteworthy because the energy is equivalent to breaking $\sim 170 \mathrm{C}-\mathrm{C}$ bonds, but the filament failure force of $\sim 3 \mathrm{nN}$ corresponds to the breaking of a single covalent bond [143]. It can therefore be surmised that no covalent bonds are broken during the process but the energy disrupts non-covalent interactions (sum of charges, van der Waals forces, and hydrogen bond interactions) during the unfolding of the filament domains, $\alpha$-helix to $\beta$-sheet transformation, and is stored in the $\beta$-sheets [109].

\section{The Role of Network Topology in Lamin Mechanics}

Network characteristics and mesh-size are recurring phenomena in a cell and changes in those are markers of disease [144]. For example, in situ particle-tracking micro-rheology of keratin networks suggested the influence of mesh size and possibly connectivity on the mechanical properties of the network under shear stress [145]. Cryo-ET data reconstructs the 3D volume of a network from images captured in different planes [146]. The networks can be analyzed using graph theory principles to obtain quantitative parameters of the network topology, i.e., a connectivity map akin to a subway chart [147]. Simulating lamin filament pushing showed that increasing the connectivity of the network increased the strength, extensibility and toughness of single filaments [111]. This may be a straightforward yet intriguing result that can be invoked to explain various observations related to changes in nuclear morphologies and associated dysfunctions in lamin-associated diseases, as well as possibly other IF-associated disease. For instance, the lamin meshwork forms ordered domains in HGPS patient cells, distorting the nuclear morphology and making it 'brittle' [148]. This concurs with the structural hypothesis that mutations cause aberrant changes in the mechanics of the lamin filaments with deleterious effects on the lamin meshwork and the nuclear envelope [149]. However, this does not rule out the generegulation hypothesis that mutations in the lamin protein affect crucial protein binding sites, thereby leading to nuclear abnormalities. It is likely that both structure and generegulation are affected and are not exclusive [150]. Breaks in connections between lamin filaments and SUN-KASH proteins, cytoskeletal filaments and nuclear membrane proteins may also perturb the lamin network topology [151]. 


\section{The Road Ahead}

The structural framework of cells has evolved to respond efficiently to different mechanical shocks and traumas. IFs are excellent examples of this phenomenon-even different isoforms of the same filament may have different roles. The first line of defense is the actin cortex abutting the cell membrane, providing a stiff, although brittle, layer under high loads. Once parts of the actin cortex are breached, the force reaches the underlying layers of IFs that are stiff and absorb shocks at low forces. However, at higher loads, IFs start to stiffen before succumbing. In the case of lamins, load-tolerance was shown to increase with stiffness [111]. A few mechanical properties of IFs are summarized in Table 1.

Table 1. Mechanical properties of intermediate filaments (IFs).

\begin{tabular}{|c|c|c|c|c|c|}
\hline IF Type & Method & $\begin{array}{c}\text { Failure } \\
\text { Force }(\mathrm{nN})\end{array}$ & Mode & Extensibility & $\begin{array}{c}\text { Energy Dissi- } \\
\text { pated/Toughness } \\
\left(\mathrm{MJ} \mathrm{m}^{-3}\right)\end{array}$ \\
\hline Desmin [7] & \multirow{4}{*}{ AFM } & \multirow{3}{*}{$\begin{array}{l}\text { 30-40 applied } \\
\text { force }^{1}\end{array}$} & \multirow{4}{*}{$\begin{array}{c}\text { Stretching the } \\
\text { filaments adsorbed on } \\
\text { a surface }\end{array}$} & 240 & \multirow{3}{*}{-} \\
\hline Keratin (K5/K14) [7] & & & & 240 & \\
\hline Neurofilaments [7] & & & & 260 & \\
\hline Desmin [8] & & 3.5 & & 240 & 50 \\
\hline Vimentin [4] & LOT & 0.6 (no failure $)^{2}$ & $\begin{array}{c}\text { Axial } \\
\text { (end-to-end) stretching }\end{array}$ & & - \\
\hline Vimentin [9] & AFM & 8 (no failure $)^{3}$ & $\begin{array}{c}\text { Axial } \\
\text { (end-to-end) stretching }\end{array}$ & 300 & - \\
\hline Lamin [10] & AFM & $\begin{array}{l}3 \text { (appar- } \\
\text { ent failure) }\end{array}$ & $\begin{array}{l}\text { Pushing perpendicular } \\
\text { to the filament axis }\end{array}$ & 250 & 147 \\
\hline Hagfish slime [11] & $\begin{array}{l}\text { Glass microbeam force } \\
\text { transducer apparatus }\end{array}$ & - & Stretching & 220 & 130 \\
\hline
\end{tabular}

AFM = Atomic force microscopy. LOT $=$ Laser optical trap. ${ }^{1}$ Maximum force applied to observe filament stretching and failure. Exact force where failure occurred was not reported. ${ }^{2}$ Force applied with LOT was in the sub-nN range. ${ }^{3}$ AFM is capable of measuring forces reaching tens of $\mathrm{nN}$.

A low force tolerance material such as F-actin forms a cortex around the cell, acting as a sensitive sensor for miniscule $\mathrm{pN}$ forces relayed from the cellular environment via the integrin receptors. The structure of IFs bestows superb mechanical properties on them-long rope-like filaments that form networks, $\alpha$-helical coiled-coils capable of sliding when stretched, strain-induced stiffening at high forces. It is intriguing, though perhaps not surprising, that despite the differences in the dimensions and sequence identities of vimentin and lamin, their mechanical characteristics are comparable [152]. It would be worth investigating the entire mechanical regime of vimentin up to $\mathrm{nN}$ forces in situ or in a close-to-native environment. Possibly, similar to lamin filaments, vimentin filaments will portray a network-dependent enhancement of their mechanical properties [114].

The concentrations of different filaments are fine-tuned depending on the cell-type. For example, lamin concentrations are regulated depending on the development stage and cell type; arteries and eye lens have cross-linked vimentin. Lamin A is predominantly present in 'harder' fibroblasts and muscle cells, and the lamina thickness depends on the cell type and the physiological state of the cell [153]. The amount of lamin A has been shown to scale with tissue stiffness [96]. Similar observations were recorded for keratin networks that undergo structural remodeling on stiffer substrates. Depending on the substrate stiffness, keratin may play an important role in modulating A-type lamin expression and mechanotransduction to the lamina [94]. It may imply that lamin expression levels in different tissues dictate the topologies of the nuclear lamin, further influencing their mechanical properties and the ability to protect the nucleus from extracellular forces.

The effect of different mutations (in the rod and tail domains) on the lamin meshwork architecture is an ongoing area of investigation. A recent study suggests that the H222P 
mutation in lamin A of mouse embryonic fibroblasts does not lead to a marked change in the lamin meshwork, although nuclear volume and chromatin organization are affected [76]. Detailed investigation is required to understand at what stage of assembly, i.e., dimer, tetramer or higher-order assemblies, do mutations cause mechanical changes.

In vitro experiments provide a good starting point to study individual elements. However, these experiments do not capture an accurate picture of IF properties in many cases, as demonstrated by paracrystalline lamin assemblies. The interplay between the different filaments and their fine tuning of cellular signaling and mechanical protection is far from clear. Ideas from bottom-up synthetic biology can be applied, for example, to mimic the nucleus and increase system complexity by reconstituting essential processes [154]. These are challenging ventures and require new approaches and techniques to completely understand the functional make-up of these complex systems. We envision that combining imaging and nano-manipulation methods and tools (e.g., AFM, LOT, cryo-EM, superresolution microscopy, MD simulations) will open avenues to correlate the structure and mechanics of cyto- and nucleoskeletal networks in situ.

Author Contributions: Conceptualization, K.T.S. and O.M.; writing-original draft preparation, K.T.S.; writing - review and editing, K.T.S. and O.M.; visualization, K.T.S. All authors have read and agreed to the published version of the manuscript.

Funding: This work was funded by the Swiss National Foundation Grant (31003A_179418) to O.M.

Acknowledgments: The authors thank Rafael Kronenberg-Tenga for designing Figure 3D and Charlie Beales for critical reading of the manuscript.

Conflicts of Interest: The authors declare no conflict of interest.

\section{References}

1. Wang, N.; Tytell, J.D.; Ingber, D.E. Mechanotransduction at a distance: Mechanically coupling the extracellular matrix with the nucleus. Nat. Rev. Mol. Cell Biol. 2009, 10, 75-82. [CrossRef] [PubMed]

2. Herrmann, H.; Aebi, U. Intermediate Filaments: Structure and Assembly. Cold Spring Harb. Perspect. Biol. 2016, 8. [CrossRef] [PubMed]

3. Turgay, Y.; Eibauer, M.; Goldman, A.; Shimi, T.; Khayat, M.; Harush, K.B.; Dubrovsky-Gaupp, A.; Sapra, K.T.; Goldman, R.; Medalia, O. The molecular architecture of lamins in somatic cells. Nature 2017, 543, 261-264. [CrossRef]

4. Block, J.; Schroeder, V.; Pawelzyk, P.; Willenbacher, N.; Köster, S. Physical properties of cytoplasmic intermediate filaments. Biochim. Biophys. Acta 2015, 1853, 3053-3064. [CrossRef]

5. Maniotis, A.J.; Chen, C.S.; Ingber, D.E. Demonstration of mechnical connections between integrins, cytoskeletal filaments, and nucleoplasm that stabilize nuclear structure. Proc. Natl. Acad. Sci. USA 1997, 94, 849-854. [CrossRef] [PubMed]

6. Yoon, K.H.; Yoon, M.; Moir, R.D.; Khuon, S.; Flitney, F.W.; Goldman, R.D. Insights into the dynamic properties of keratin intermediate filaments in living epithelial cells. J. Cell Biol. 2001, 153, 503-516. [CrossRef] [PubMed]

7. Charrier, E.; Janmey, P.A. Mechanical properties of intermediate filament proteins. Methods Enymol. 2016, 568, 35-57.

8. Broussard, J.A.; Jaiganesh, A.; Zarkoob, H.; Conway, D.E.; Dunn, A.R.; Espinosa, H.D.; Janmey, P.A.; Green, K.J. Scaling up single-cell mechanics to multicellular tissues-the role of the intermediate filament-desmosome network J. Cell Sci. $2020,133$. [CrossRef]

9. Storm, C.; Pastore, J.J.; MacKintosh, F.C.; Lubensky, T.C.; Janmey, P.A. Nonlinear elasticity in biological gels. Nature 2005, 435, 191-194. [CrossRef] [PubMed]

10. Janmey, P.A.; Euteneuer, U.; Traub, P.; Schliwa, M. Viscoelastic properties of vimentin compared with other filamentous biopolymer networks. J. Cell Biol. 1991, 113, 155-160. [CrossRef] [PubMed]

11. Kreplak, L.; Bär, H.; Leterrier, J.F.; Herrmann, H.; Aebi, U. Exploring the mechanical behavior of single intermediate filaments. J. Mol. Biol. 2005, 354, 569-577. [CrossRef] [PubMed]

12. Zingerman-Koladko, I.; Khayat, M.; Harapin, J.; Shoseyov, O.; Gruenbaum, Y.; Salman, A.; Medalia, O.; Ben-Harush, K. The assembly of C. elegans lamins into macroscopic fibers. J. Mech. Behav. Biomed. Mater. 2016, 63, 35-43. [CrossRef]

13. Hu, J.; Li, Y.; Hao, Y.; Zheng, T.; Gupta, S.K.; Parada, G.A.; Wu, H.; Lin, S.; Wang, S.; Zhao, X.; et al. High stretchability, strength, and toughness of living cells enabled by hyperelastic vimentin intermediate filaments. Proc. Natl. Acad. Sci. USA 2019, 116, 17175-17180. [CrossRef]

14. Lazarides, E. Intermediate filaments as mechanical integrators of cellular space. Nature 1980, 283, 249-256. [CrossRef]

15. Eriksson, J.E.; Dechat, T.; Grin, B.; Helfland, B.; Mendez, M.; Pallari, H.-M.; Goldman, R.D. Introducing intermediate filaments: From discovery to disease. J. Clin. Investig. 2009, 119, 1763-1771. [CrossRef] 
16. Dahl, K.N.; Kahn, S.M.; Wilson, K.L.; Discher, D.E. The nuclear envelope lamina network has elasticity and a compressibility limit suggestive of a molecular shock absorber. J. Cell Sci. 2004, 117, 4779-4786. [CrossRef]

17. Rowat, A.C.; Foster, L.J.; Nielsen, M.M.; Weiss, M.; Ipsen, J.H. Characterization of the elastic properties of the nuclear envelope. J. $R$ Soc. Interface 2005, 2, 63-69. [CrossRef] [PubMed]

18. Wong, X.; Loo, T.H.; Stewart, C.L. LINC complex regulation of genome organization and function. Curr. Opin. Genet. Dev. 2021, 67, 130-141. [CrossRef] [PubMed]

19. Isermann, P.; Lammerding, J. Nuclear mechanics and mechanotransduction in health and disease. Curr. Biol. 2013, 23, 1113-1121. [CrossRef]

20. Tajik, A.; Zhang, Y.; Wei, F.; Sun, J.; Jia, Q.; Zhou, W.; Singh, R.; Khanna, N.; Belmont, A.S.; Wang, N. Transcription upregulation via force-induced direct stretching of chromatin. Nat. Mater. 2016, 15, 1287-1296. [CrossRef]

21. Fletcher, D.A.; Mullins, R.D. Cell mechanics and the cytoskeleton. Nature 2010, 463, 485-492. [CrossRef]

22. Smoler, M.; Coceano, G.; Testa, I.; Bruno, L.; Levi, V. Apparent stiffness of vimentin intermediate filaments in living cells and its relation with other cytoskeletal polymers. BBA-Mol. Cell Res. 2020, 1867, 118726-118734. [CrossRef]

23. Szeverenyi, I.; Cassidy, A.J.; Chung, C.W.; Lee, B.T.; Common, J.E.; Ogg, S.C.; Chen, H.; Sim, S.Y.; Goh, W.L.; Ng, K.W.; et al. The Human Intermediate Filament Database: Comprehensive information on a gene family involved in many human diseases. Hum. Mutat. 2008, 29, 351-360. [CrossRef] [PubMed]

24. Omary, M.B. "IF-pathies": A broad spectrum of intermediate filament-associated diseases. J. Clin. Investig. 2009, 119, 1756-1762. [CrossRef] [PubMed]

25. Clemen, C.S.; Herrmann, H.; Strelkov, S.V.; Schröder, R. Desminopathies: Pathology and mechanisms. Acta Neuropathol. 2013, 125, 47-75. [CrossRef]

26. Omary, M.B.; Coulombe, P.A.; McLean, W.H. Intermediate filament proteins and their associated diseases. N. Engl. J. Med. 2004, 351, 2087-2100. [CrossRef]

27. Osborn, M. Intermediate filaments as histologic markers: An overview. J. Investig. Dermat. 1983, 81, 104s-109s. [CrossRef] [PubMed]

28. Leader, M.; Collins, M.; Patel, J.; Henry, K. Vimentin: An evaluation of its role as a tumour marker. Histopathology 2007, 11, 63-72. [CrossRef]

29. Karantza, V. Keratins in health and cancer: More than mere epithelial cell markers. Oncogene 2011, 30, 127-138. [CrossRef]

30. Sharma, P.; Alsharif, S.; Fallatah, A.; Chung, B.M. Intermediate filaments as effectors of cancer development and metastasis: A focus on keratins, vimentin, and nestin. Cells 2019, 8, 497. [CrossRef] [PubMed]

31. Ramos, I.; Stamatakis, K.; Oeste, C.L.; Pérez-Sala, D. Vimentin as a multifaceted player and potential therapeutic target in viral infections. Int. J. Mol. Sci. 2020, 21, 4675. [CrossRef] [PubMed]

32. Karoutas, A.; Akhtar, A. Functional mechanisms and abnormalities of the nuclear lamina. Nat. Cell Biol. 2021, 23, 116-126. [CrossRef] [PubMed]

33. Dubik, N.; Mai, S. Lamin A/C: Function in normal and tumor cells. Cancers 2020, 12, 3688. [CrossRef]

34. Parry, D.A.; Martin, C.A.; Greene, P.; Marsh, J.A.; Genomics England Research, C.; Blyth, M.; Cox, H.; Donnelly, D.; Greenhalgh, L.; Greville-Heygate, S.; et al. Heterozygous lamin B1 and lamin B2 variants cause primary microcephaly and define a novel laminopathy. Genet. Med. 2021, 23, 408-414. [CrossRef]

35. Gruenbaum, Y.; Foisner, R. Lamins: Nuclear intermediate filament proteins with fundamental functions in nuclear mechanics and genome regulation. Annu. Rev. Biochem. 2015, 84, 131-164. [CrossRef]

36. Tatli, M.; Medalia, O. Insight into the functional organization of nuclear lamins in health and disease. Curr. Opin. Cell Biol. 2018, 54, 72-79. [CrossRef]

37. Guelen, L.; Pagie, L.; Brasset, E.; Meuleman, W.; Faza, M.B.; Talhout, W.; Eussen, B.H.; de Klein, A.; Wessels, L.; de Laat, W.; et al. Domain organization of human chromosomes revealed by mapping of nuclear lamina interactions. Nature 2008, 453, 948-951. [CrossRef] [PubMed]

38. Bridger, J.M.; Foeger, N.; Kill, I.R.; Herrmann, H. The nuclear lamina. Both a structural framework and a platform for genome organization. FEBS J. 2007, 274, 1354-1361. [CrossRef]

39. Zuela, N.; Gruenbaum, Y. Intermediate filaments in Caenorhabditis elegans. Methods Enzymol. 2016, 568, 661-679.

40. Jarrin, M.; Young, L.; Wu, W.; Girkin, J.M.; Quinlan, R.A. In vivo, ex vivo, and in vitro approaches to study intermediate filaments in the eye lens. Methods Enzymol. 2016, 568, 581-611.

41. Aebi, U.; Cohn, J.; Buhle, L.; Gerace, L. The nuclear lamina is a meshwork of intermediate-type filaments. Nature 1986, 323, 560-564. [CrossRef] [PubMed]

42. Bohnekamp, J.; Cryderman, D.E.; Thiemann, D.A.; Magin, T.M.; Wallrath, L.L. Using Drosophila for studies of intermediate filaments. Methods Enzymol. 2016, 568, 707-726.

43. Crick, F.H.C. Is $\alpha$-keratin a coiled coil? Nature 1952, 170, 882-883. [CrossRef] [PubMed]

44. Steinert, P.M.; Parry, D.A.D. Intermediate filaments: Conformity and diversity of expression and structure. Ann. Rev. Cell Biol. 1985, 1, 41-65. [CrossRef] [PubMed]

45. Chernyatina, A.A.; Guzenko, D.; Strelkov, S.V. Intermediate filament structure: The bottom-up approach. Curr. Opin. Cell Biol. 2015, 32, 65-72. [CrossRef] [PubMed] 
46. Goldie, K.N.; Wedig, T.; Mitra, A.K.; Aebi, U.; Herrmann, H.; Hoenger, A. Dissecting the 3-D structure of vimentin intermediate filaments by cryo-electron tomography. J. Struct. Biol. 2007, 158, 378-385. [CrossRef]

47. Eibauer, M.; Weber, M.S.; Turgay, Y.; Sivagurunathan, S.; Goldman, R.D.; Medalia, O. The molecular architecture of vimentin filaments. bioRxiv 2021. [CrossRef]

48. Weber, M.S.; Eibauer, M.; Sivagurunathan, S.; Magin, T.M.; Goldman, R.D.; Medalia, O. Structural heterogeneity of cellular $\mathrm{K} 5 / \mathrm{K} 14$ filaments as revealed by cryo-electron microscopy. eLife 2021. [CrossRef]

49. Strelkov, S.V.; Herrmann, H.; Geisler, N.; Wedig, T.; Zimbelmann, R.; Aebi, U.; Burkhard, P. Conserved segments 1A and 2B of the intermediate filament dimer: Their atomic structures and role in filament assembly. EMBO J. 2002, 21, 1255-1266. [CrossRef]

50. Chernyatina, A.A.; Nicolet, S.; Aebi, U.; Herrmann, H.; Strelkov, S.V. Atomic structure of the vimentin central alpha-helical domain and its implications for intermediate filament assembly. Proc. Natl. Acad. Sci. USA 2012, 109, 13620-13625. [CrossRef]

51. Strelkov, S.V.; Schumacher, J.; Burkhard, P.; Aebi, U.; Herrmann, H. Crystal structure of the human lamin A coil 2B dimer: Implications for the head-to-tail association of nuclear lamins. J. Mol. Biol. 2004, 343, 1067-1080. [CrossRef] [PubMed]

52. Lee, C.-H.; Kim, M.-S.; Chung, B.M.; Leahy, D.J.; Coulombe, P.A. Structural basis for heteromeric assembly and perinuclear organization of keratin filaments. Nat. Struct. Mol. Biol. 2012, 19, 707-715. [CrossRef]

53. Chernyatina, A.A.; Hess, J.F.; Guzenko, D.; Voss, J.C.; Strelkov, S.V. How to study intermediate filaments in atomic detail. Methods Enzymol. 2016, 568, 3-33. [PubMed]

54. De Leeuw, R.; Gruenbaum, Y.; Medalia, O. Nuclear lamins: Thin filaments with major functions. Trends Cell Biol. 2018, 28, 34-45. [CrossRef]

55. Goldberg, M.W.; Huttenlauch, I.; Hutchison, C.J.; Stick, R. Filaments made from A-and B-type lamins differ in structure and organization. J. Cell Sci. 2008, 121, 215-225. [CrossRef] [PubMed]

56. Foeger, N.; Wiesel, N.; Lotsch, D.; Mucke, N.; Kreplak, L.; Aebi, U.; Gruenbaum, Y.; Herrmann, H. Solubility properties and specific assembly pathways of the B-type lamin from Caenorhabditis elegans. J. Struct. Biol. 2006, 155, 340-350. [CrossRef]

57. Strelkov, S.V.; Herrmann, H.; Geisler, N.; Lustig, A.; Ivaninskii, S.; Zimbelmann, R.; Burkhard, P.; Aebi, U. Divide-and-conquer crystallographic approach towards an atomic structure of intermediate filaments. J. Mol. Biol. 2001, 306, 773-781. [CrossRef]

58. Shimi, T.; Kittisopikul, M.; Tran, J.; Goldman, A.E.; Adam, S.A.; Zheng, Y.; Jaqaman, K.; Goldman, R.D. Structural organization of nuclear lamins A, C, B1, and B2 revealed by superresolution microscopy. Mol. Biol. Cell 2015, 26, 4075-4086. [CrossRef] [PubMed]

59. Kittisopikul, M.; Shimi, T.; Tatli, M.; Tran, J.R.; Zheng, Y.; Medalia, O.; Jaqaman, K.; Adam, S.A.; Goldman, R.D. Computational analyses reveal spatial relationships between nuclear pore complexes and specific lamins. J. Cell Biol. 2021, 220 , e202007082. [CrossRef] [PubMed]

60. Asano, S.; Engel, B.D.; Baumeister, W. In situ cryo-electron tomography: A post-reductionist approach to structural biology. J. Mol. Biol. 2016, 428, 332-343. [CrossRef]

61. Robinson, C.V.; Sali, A.; Baumeister, W. The molecular sociology of the cell. Nature 2007, 450, 973-982. [CrossRef]

62. Medalia, O.; Weber, I.; Frangakis, A.S.; Nicastro, D.; Gerisch, G.; Baumeister, W. Macromolecular architecture in eukaryotic cells visualized by cryoelectron tomography. Science 2002, 298, 1209-1213. [CrossRef] [PubMed]

63. Mahamid, J.; Pfeffer, S.; Schaffer, M.; Villa, E.; Danev, R.; Cuellar, L.K.; Förster, F.; Hyman, A.A.; Plitzko, J.M.; Baumeister, W. Visualizing the molecular sociology at the HeLa cell nuclear periphery. Science 2016, 351, 969-972. [CrossRef]

64. Harapin, J.; Bormel, M.; Sapra, K.T.; Brunner, D.; Kaech, A.; Medalia, O. Structural analysis of multicellular organisms with cryo-electron tomography. Nat. Methods 2015, 12, 634-636. [CrossRef]

65. Martins, B.; Sorrentino, S.; Chung, W.L.; Tatli, M.; Medalia, O.; Eibauer, M. Unveiling the polarity of actin filaments by cryoelectron tomography. Structure 2021, 29, 488-498.e484. [CrossRef] [PubMed]

66. Zila, V.; Margiotta, E.; Turoňová, B.; Müller, T.G.; Zimmerli, C.E.; Mattei, S.; Allegretti, M.; Börner, K.; Rada, J.; Müller, B.; et al. Cone-shaped HIV-1 capsids are transported through intact nuclear pores. Cell 2021, 184, 1032-1046. [CrossRef] [PubMed]

67. Grossman, E.; Dahan, I.; Stick, R.; Goldberg, M.W.; Gruenbaum, Y.; Medalia, O. Filaments assembly of ectopically expressed Caenorhabditis elegans lamin within Xenopus oocytes. J. Struct. Biol. 2012, 177, 113-118. [CrossRef] [PubMed]

68. Ben-Harush, K.; Wiesel, N.; Frenkiel-Krispin, D.; Moeller, D.; Soreq, E.; Aebi, U.; Herrmann, H.; Gruenbaum, Y.; Medalia, O. The supramolecular organization of the C. elegans nuclear lamin filament. J. Mol. Biol. 2009, 386, 1392-1402. [CrossRef]

69. Bank, E.M.; Ben-Harush, K.; Feinstein, N.; Medalia, O.; Gruenbaum, Y. Structural and physiological phenotypes of disease-linked lamin mutations in C. elegans. J. Struct. Biol. 2012, 177, 106-112. [CrossRef]

70. Taimen, P.; Pfleghaar, K.; Shimi, T.; Möller, D.; Ben-Harush, K.; Erdos, M.R.; Adam, S.A.; Herrmann, H.; Medalia, O.; Collins, F.S.; et al. A progeria mutation reveals functions for lamin A in nuclear assembly, architecture, and chromosome organization. Proc. Natl. Acad. Sci. USA 2009, 106, 20788-20793. [CrossRef] [PubMed]

71. Dittmer, T.A.; Misteli, T. The lamin protein family. Genome Biol. 2011, 12. [CrossRef] [PubMed]

72. Ahn, J.; Jo, I.; Kang, S.M.; Hong, S.; Kim, S.; Jeong, S.; Kim, Y.H.; Park, B.J.; Ha, N.C. Structural basis for lamin assembly at the molecular level. Nat. Commun. 2019, 10, 3757. [CrossRef]

73. Lilina, A.V.; Chernyatina, A.A.; Guzenko, D.; Strelkov, S.V. Lateral A11 type tetramerization in lamins. J. Struct. Biol. 2020, 209, 107404. [CrossRef] [PubMed]

74. Stuurman, N.; Heins, S.; Aebi, U. Nuclear lamins: Their structure, assembly, and interactions. J. Struct. Biol. 1998, 122, 42-66. [CrossRef] 
75. Heitlinger, E.; Peter, M.; Häner, M.; Lustig, A.; Aebi, U.; Nigg, E.A. Expression of chicken lamin B2 in Escherichia coli: Characterization of its structure, assembly, and molecular interactions. J. Cell Biol. 1991, 113, 485-495. [CrossRef]

76. Kronenberg-Tenga, R.; Tatli, M.; Eibauer, M.; Wu, W.; Shin, J.Y.; Bonne, G.; Worman, H.J.; Medalia, O. A lamin A/C variant causing striated muscle disease provides insights into filament organization. J. Cell Sci. 2021, 134, jcs256156. [CrossRef]

77. Nmezi, B.; Xu, J.; Fu, R.; Armiger, T.J.; Rodriguez-Bey, G.; Powell, J.S.; Ma, H.; Sullivan, M.; Tu, Y.; Chen, N.Y.; et al. Concentric organization of A- and B-type lamins predicts their distinct roles in the spatial organization and stability of the nuclear lamina. Proc. Natl. Acad. Sci. USA 2019, 116, 4307-4315. [CrossRef]

78. Funkhouser, C.M.; Sknepnek, R.; Shimi, T.; Goldman, A.E.; Goldman, R.D.; Olvera de la Cruz, M. Mechanical model of blebbing in nuclear lamin meshworks. Proc. Natl. Acad. Sci. USA 2013, 110, 3248-3253. [CrossRef] [PubMed]

79. Shimi, T.; Pfleghaar, K.; Kojima, S.; Pack, C.G.; Solovei, I.; Goldman, A.E.; Adam, S.A.; Shumaker, D.K.; Kinjo, M.; Cremer, T.; et al. The A-and B-type nuclear lamin networks: Microdomains involved in chromatin organization and transcription. Genes Dev. 2008, 22, 3409-3421. [CrossRef]

80. Chatzifrangkeskoua, M.; Kah, D.; Lange, J.R.; Goldmann, W.H.; Muchira, A. Mutated lamin A modulates stiffness in muscle cells. Biochem. Biophys. Res. Comm. 2020, 529, 861-867. [CrossRef] [PubMed]

81. Köster, S.; Weitz, D.; Goldman, R.D.; Aebi, U.; Herrmann, H. Intermediate filament mechanics in vitro and in the cell: From coiled coils to filaments, fibers and networks. Curr. Opin. Cell Biol. 2015, 32, 82-91. [CrossRef]

82. Wintner, O.; Hirsch-Attas, N.; Schlossberg, M.; Brofman, F.; Friedman, R.; Kupervaser, M.; Kitsberg, D.; Buxboim, A. A unified linear viscoelastic model of the cell nucleus defines the mechanical contributions of lamins and chromatin. Adv. Sci. (Weinh) 2020, 7, 1901222. [CrossRef]

83. Schäpe, J.; Prausse, S.; Radmacher, M.; Stick, R. Influence of lamin A on the mechanical properties of amphibian oocyte nuclei measured by atomic force microscopy. Biophys. J. 2009, 96, 4319-4325. [CrossRef]

84. Eriksson, M.; Brown, W.T.; Gordon, L.B.; Glynn, M.W.; Singer, J.; Scott, L.; Erdos, M.R.; Robbins, C.M.; Moses, T.Y.; Berglund, P.; et al. Recurrent de novo point mutations in lamin A cause Hutchinson-Gilford progeria syndrome. Nature 2003, 423, 293-298. [CrossRef]

85. Kaufmann, A.; Heinemann, F.; Radmacher, M.; Stick, R. Amphibian oocyte nuclei expressing lamin A with the progeria mutation E145K exhibit an increased elastic modulus. Nucleus 2011, 2, 310-319. [CrossRef]

86. Apte, K.; Stick, R.; Radmacher, M. Mechanics in human fibroblasts and progeria: Lamin A mutation E145K results in stiffening of nuclei. J. Mol. Recognit. 2016, 30. [CrossRef] [PubMed]

87. Liu, H.; Wen, J.; Xiao, Y.; Liu, J.; Hopyan, S.; Radisic, M.; Simmons, C.A.; Sun, Y. In situ mechanical characterization of the cell nucleus by atomic force microscopy. ACS Nano 2014, 8, 3821-3828. [CrossRef] [PubMed]

88. Ingber, D.E.; Wang, N.; Stamenovic, D. Tensegrity, cellular biophysics, and the mechanics of living systems. Rep. Prog. Phys. 2014, 77, 046603. [CrossRef] [PubMed]

89. Patteson, A.E.; Vahabikashi, A.; Pogoda, K.; Adam, S.A.; Mandal, K.; Kittisopikul, M.; Sivagurunathan, S.; Goldman, A.; Goldman, R.D.; Janmey, P.A. Vimentin protects cells against nuclear rupture and DNA damage during migration. J. Cell Biol. 2019, 218, 4079-4092. [CrossRef]

90. Wu, P.H.; Aroush, D.R.; Asnacios, A.; Chen, W.C.; Dokukin, M.E.; Doss, B.L.; Durand-Smet, P.; Ekpenyong, A.; Guck, J.; Guz, N.V.; et al. A comparison of methods to assess cell mechanical properties. Nat. Methods 2018, 15, 491-498. [CrossRef]

91. Wang, B.; Yang, W.; McKittrick, J.; Meyers, M.A. Keratin: Structure, mechanical properties, occurrence in biological organisms, and effortsat bioinspiration. Prog. Mat. Sci. 2016, 76, 229-318. [CrossRef]

92. Ramms, L.; Fabris, G.; Windoffer, R.; Schwarz, N.; Springer, R.; Zhou, C.; Lazar, J.; Stiefel, S.; Hersch, N.; Schnakenberg, U.; et al. Keratins as the main component for the mechanical integrity of keratinocytes. Proc. Natl. Acad. Sci. USA 2013, 110, 18513-18518. [CrossRef] [PubMed]

93. Seltmann, K.; Fritsch, A.W.; Käs, J.A.; Magin, T.M. Keratins significantly contribute to cell stiffness and impact invasive behavior. Proc. Natl. Acad. Sci. USA 2013, 110, 18507-18512. [CrossRef]

94. Laly, A.C.; Sliogeryte, K.; Pundel, O.J.; Ross, R.; Keeling, M.C.; Avisetti, D.; Waseem, A.; Gavara, N.; Connelly, J.T. The keratin network of intermediate filaments regulates keratinocyte rigidity sensing and nuclear mechanotransduction. Sci. Adv. 2021, 7, eabd6187. [CrossRef] [PubMed]

95. Mendez, M.G.; Restle, D.; Janmey, P.A. Vimentin enhances cell elastic behavior and protects against compressive stress. Biophys. J. 2014, 107, 314-323. [CrossRef] [PubMed]

96. Swift, J.; Ivanovska, I.L.; Buxboim, A.; Harada, T.; Dingal, D.P.; Pinter, J.; Pajerowski, D.J.; Spinler, K.R.; Shin, J.-W.; Tewari, M.; et al. Nuclear lamin-A scales with tissue stiffness and enhances matrix-directed differentiation. Science 2013, 341, 1240104. [CrossRef]

97. Ma, L.; Yamada, S.; Wirtz, D.; Coulombe, P.A. A 'hot-spot' mutation alters the mechanical properties of keratin filament networks. Nat. Cell Biol. 2001, 3, 503-506. [CrossRef]

98. Panorchan, P.; Schafer, B.W.; Wirtz, D.; Tseng, Y. Nuclear envelope breakdown requires overcoming the mechanical integrity of the nuclear lamina. J. Biol. Chem. 2004, 279, 43462-43467. [CrossRef] [PubMed]

99. Kasza, K.E.; Rowat, A.C.; Liu, J.; Angelini, T.E.; Brangwynne, C.P.; Koenderink, G.H.; Weitz, D.A. The cell as a material. Curr. Opin. Cell Biol. 2007, 19, 101-107. [CrossRef] 
100. Pegoraro, A.F.; Janmey, P.A.; Weitz, D.A. Mechanical properties of the cytoskeleton and cells. Cold Spring Harb. Perspect. Biol. 2007, 9, a022038. [CrossRef]

101. Fudge, D.S.; Gardner, K.H.; Forsyth, V.T.; Riekel, C.; Gosline, J.M. The mechanical properties of hydrated intermediate filaments: Insights from hagfish slime threads. Biophys. J. 2003, 85, 2015-2027. [CrossRef]

102. Kreplak, L.; Herrmann, H.; Aebi, U. Tensile properties of single desmin intermediate filaments. Biophys. J. 2008, 94, $2790-2799$. [CrossRef] [PubMed]

103. Guzmán, C.; Jeney, S.; Kreplak, L.; Kasas, S.; Kulik, A.J.; Aebi, U.; Forró, L. Exploring the mechanical properties of single vimentin intermediate filaments by atomic force microscopy. J. Mol. Biol. 2006, 360, 623-630. [CrossRef]

104. Mücke, N.; Kreplak, L.; Kirmse, R.; Wedig, T.; Herrmann, H.; Aebi, U.; Langowski, J. Assessing the flexibility of intermediate filaments by atomic force microscopy. J. Mol. Biol. 2004, 335, 1241-1250. [CrossRef]

105. Chang, W.; Worman, H.J.; Gundersen, G.G. Accessorizing and anchoring the LINC complex for multifunctionality. J. Cell Biol. 2015, 208, 11-22. [CrossRef] [PubMed]

106. Qin, Z.; Kreplak, L.; Buehler, M.J. Nanomechanical properties of vimentin intermediate filament dimers. Nanotechnology 2009, 20, 425101. [CrossRef] [PubMed]

107. Ashkin, A.; Dziedzic, J.M. Optical trapping and manipulation of viruses and bacteria. Science 1987, 235, 1517-1520. [CrossRef]

108. Block, J.; Witt, H.; Candelli, A.; Peterman, E.J.G.; Wuite, G.J.L.; Janshoff, A.; Köster, S. Nonlinear loading-rate-dependent force response of individual vimentin intermediate filaments to applied strain. Phy. Rev. Lett. 2017, 118, 048101. [CrossRef] [PubMed]

109. Block, J.; Witt, H.; Candelli, A.; Danes, J.C.; Peterman, E.J.G.; Wuite, G.J.L.; Janshoff, A.; Köster, S. Viscoelastic properties of vimentin originate from nonequilibrium conformational changes. Sci. Adv. 2018, 4, eaat1161. [CrossRef]

110. Forsting, J.; Kraxner, J.; Witt, H.; Janshoff, A.; Köster, S. Vimentin intermediate filaments undergo irreversible conformational changes during cyclic loading. Nano Lett. 2019, 19, 7349-7356. [CrossRef] [PubMed]

111. Sapra, K.T.; Qin, Z.; Dubrovsky-Gaupp, A.; Aebi, U.; Müller, D.J.; Buehler, M.J.; Medalia, O. Nonlinear mechanics of lamin filaments and the meshwork topology build an emergent nuclear lamina. Nat. Commun. 2020, 11. [CrossRef]

112. Lorenz, C.; Forsting, J.; Schepers, A.V.; Kraxner, J.; Bauch, S.; Witt, H.; Klumpp, S.; Köster, S. Lateral subunit coupling determines intermediate filament mechanics. Phy. Rev. Lett. 2019, 123, 188102. [CrossRef]

113. Lin, Y.-C.; Yao, N.Y.; Broedersz, C.P.; Herrmann, H.; MacKintosh, F.C.; Weitz, D.A. Origins of elasticity in intermediate filament networks. Phy. Rev. Lett. 2010, 104, 058101. [CrossRef] [PubMed]

114. Lin, Y.-C.; Broedersz, C.P.; Rowat, A.C.; Wedig, T.; Herrmann, H.; MacKintosh, F.C.; Weitz, D.A. Divalent cations crosslink vimentin intermediate filament tail domains to regulate network mechanics. J. Mol. Biol. 2010, 399, 637-644. [CrossRef]

115. Schepers, A.V.; Lorenz, C.; Köster, S. Tuning intermediate filament mechanics by variation of $\mathrm{pH}$ and ion charges. Nanoscale 2020, 12, 15236-15245. [CrossRef]

116. Snider, N.T.; Omary, M.B. Post-translational modifications of intermediate filament proteins: Mechanisms and functions. Nat. Rev. Mol. Cell Biol. 2014, 15, 163-177. [CrossRef] [PubMed]

117. Kraxner, J.; Lorenz, C.; Menzel, J.; Parfentev, I.; Silbern, I.; Denz, M.; Urlaub, H.; Schwappach, B.; Köster, S. Post-translational modifications soften vimentin intermediate filaments. Nanoscale 2021, 13, 380-387. [CrossRef]

118. Eriksson, J.E.; He, T.; Trejo-Skalli, A.V.; Härmälä-Braskén, A.S.; Hellman, J.; Chou, Y.H.; Goldman, R.D. Specific in vivo phosphorylation sites determine the assembly dynamics of vimentin intermediate filaments. J. Cell Sci. 2004, 117, 919-932. [CrossRef] [PubMed]

119. Zhu, Q.-S.; Rosenblatt, K.; Huang, K.-L.; Lahat, G.; Brobey, R.; Bolshakov, S.; Nguyen, T.; Ding, Z.; Belousov, R.; Bill, K.; et al. Vimentin is a novel AKT1 target mediating motility and invasion. Oncogene 2011, 30, 457-470. [CrossRef] [PubMed]

120. Torvaldson, E.; Kochin, V.; Eriksson, J.E. Phosphorylation of lamins determine their structural properties and signaling functions. Nucleus 2015, 6, 166-171. [CrossRef]

121. Sawant, M.S.; Leube, R.E. Consequences of keratin phosphorylation for cytoskeletal organization and epithelial functions. Int. Rev. Cell Mol. Biol. 2017, 330, 171-225.

122. Denais, C.M.; Gilbert, R.M.; Isermann, P.; McGregor, A.L.; Lindert, M.; Weigelin, B.; Davidson, P.M.; Friedl, P.; Wolf, K.; Lammerding, J. Nuclear envelope rupture and repair during cancer cell migration. Science 2016, 352, 353-358. [CrossRef]

123. Earle, A.J.; Kirby, T.J.; Fedorchak, G.R.; Isermann, P.; Patel, J.; Iruvanti, S.; Moore, S.A.; Bonne, G.; Wallrath, L.L.; Lammerding, J. Mutant lamins cause nuclear envelope rupture and DNA damage in skeletal muscle cells. Nat. Mater. 2020, 19, 464-473. [CrossRef]

124. Raab, M.; Gentili, M.; de Belly, H.; Thiam, H.R.; Vargas, P.; Jimenez, A.J.; Lautenschlaeger, F.; Voituriez, R.; Lennon-Duménil, A.M.; Manel, N.; et al. ESCRT III repairs nuclear envelope ruptures during cell migration to limit DNA damage and cell death. Science 2016, 352, 359-362. [CrossRef]

125. Chen, N.Y.; Kim, P.; Weston, T.A.; Edillo, L.; Tu, Y.; Fong, L.G.; Young, S.G. Fibroblasts lacking nuclear lamins do not have nuclear blebs or protrusions but nevertheless have frequent nuclear membrane ruptures. Proc. Natl. Acad. Sci. USA 2018, 115, 10100-10105. [CrossRef]

126. Dahl, K.N.; Engler, A.J.; Pajerowski, D.J.; Discher, D.E. Power-law rheology of isolated nuclei with deformation mapping of nuclear substructures. Biophys. J. 2005, 89, 2855-2864. [CrossRef]

127. Neelam, S.; Chancellor, T.J.; Li, Y.; Nickerson, J.A.; Roux, K.J.; Dickinson, R.B.; Lele, T.P. Direct force probe reveals the mechanics of nuclear homeostasis in the mammalian cell. Proc. Natl. Acad. Sci. USA 2015, 112, 5720-5725. [CrossRef] 
128. Lammerding, J.; Schulze, C.P.; Takahashi, T.; Kozlov, S.; Sullivan, T.; Kamm, R.D.; Stewart, C.L.; Lee, R.T. Lamin A/C deficiency causes defective nuclear mechanics and mechanotransduction. J. Clin. Investig. 2004, 113, 370-378. [CrossRef] [PubMed]

129. Tenga, R.; Medalia, O. Structure and unique mechanical aspects of nuclear lamin filaments. Curr. Opin. Struct. Biol. 2020, 64, 152-159. [CrossRef] [PubMed]

130. Khayat, M.; Deri, S.; Wolf, D.; Trigano, T.; Medalia, O.; Ben-Harush, K. Biomimetic nuclear lamin fibers with remarkable toughness and stiffness. Int. J. Biol. Macromol. 2020, 163, 2060-2067. [CrossRef] [PubMed]

131. Hutchison, C.J. Lamins: Building blocks or regulators of gene expression? Nat. Rev. Mol. Cell Biol. 2002, 3, 848-858. [CrossRef] [PubMed]

132. Bera, M.; Ainavarapu, S.R.K.; Sengupta, K. Significance of $1 \mathrm{~B}$ and 2B domains in modulating elastic properties of lamin A. Sci. Rep. 2016, 6, 27879. [CrossRef] [PubMed]

133. Zhang, H.; Ackbarow, T.; Buehler, M.J. Muscle dystrophy single point mutation in the 2B segment of lamin A does not affect the mechanical properties at the dimer level. J. Biomech. 2008, 41, 1295-1301. [CrossRef] [PubMed]

134. Qin, Z.; Buehler, M.J. Flaw tolerance of nuclear intermediate filament lamina under extreme mechanical deformation. ACS Nano 2011, 5, 3034-3042. [CrossRef]

135. Hatch, E.M.; Hetzer, M.W. Nuclear envelope rupture is induced by actin-based nucleus confinement. J. Cell Biol. 2016, 215, 27-36. [CrossRef]

136. Friedl, P.; Wolf, K.; Lammerding, J. Nuclear mechanics during cell migration. Curr. Opin. Cell Biol. 2011, 23, 55-64. [CrossRef] [PubMed]

137. Guilluy, C.; Osborne, L.D.; Van Landeghem, L.; Sharek, L.; Superfine, R.; Garcia-Mata, R.; Burridge, K. Isolated nuclei adapt to force and reveal a mechanotransduction pathway in the nucleus. Nat. Cell Biol. 2014, 16, 376-381. [CrossRef]

138. Stephens, A.D.; Banigan, E.J.; Adam, S.A.; Goldman, R.D.; Marko, J.F. Chromatin and lamin A determine two different mechanical response regimes of the cell nucleus. Mol. Biol. Cell 2017, 28, 1984-1996. [CrossRef]

139. Qin, Z.; Buehler, M.J. Mechanical properties of crosslinks controls failure mechanism of hierarchical intermediate filament networks. Theor. Appl. Mech. Lett. 2012, 2, 014005. [CrossRef]

140. Lee, C.; Wei, X.; Kysar, J.W.; Hone, J. Measurement of the elastic properties and intrinsic strength of monolayer graphene. Science 2008, 321, 385-388. [CrossRef]

141. Cranford, S.W.; Tarakanova, A.; Pugno, N.M.; Buehler, M.J. Nonlinear material behaviour of spider silk yields robust webs. Nature 2012, 482, 72-76. [CrossRef]

142. Thompson, J.B.; Kindt, J.H.; Drake, B.; Hansma, H.G.; Morse, D.E.; Hansma, P.K. Bone indentation recovery time correlates with bond reforming time. Nature 2001, 414, 773-776. [CrossRef]

143. Grandbois, M.; Beyer, M.; Rief, M.; Clausen-Schaumann, H.; Gaub, H.E. How strong is a covalent bond? Science 1999, 283, 1727-1730. [CrossRef] [PubMed]

144. Vidal, M.; Cusick, M.E.; Barabási, A.L. Interactome networks and human disease. Cell 2011, 144, 986-998. [CrossRef] [PubMed]

145. Sivaramakrishnan, S.; DeGiulio, J.V.; Lorand, L.; Goldman, R.D.; Ridge, K.M. Micromechanical properties of keratin intermediate filament networks. Proc. Natl. Acad. Sci. USA 2008, 105, 889-894. [CrossRef] [PubMed]

146. Dubrovsky, A.; Sorrentino, S.; Harapin, J.; Sapra, K.T.; Medalia, O. Developments in cryo-electron tomography for in situ structural analysis. Arch. Biochem. Biophys. 2015, 581, 78-85. [CrossRef] [PubMed]

147. Barabasi, A.-L. Network Science; Cambridge University Press: Cambridge, UK, 2016.

148. Dahl, K.N.; Scaffidi, P.; Islam, M.F.; Yodh, A.G.; Wilson, K.L.; Misteli, T. Distinct structural and mechanical properties of the nuclear lamina in Hutchinson-Gilford progeria syndrome. Proc. Natl. Acad. Sci. USA 2006, 103, 10271-10276. [CrossRef]

149. Hutchison, C.J.; Worman, H.J. A-type lamins: Guardians of the soma? Nat. Cell Biol. 2004, 6, 1062-1067. [CrossRef]

150. Osmanagic-Myers, S.; Foisner, R. The structural and gene expression hypotheses in laminopathic diseases-not so different after all. Mol. Biol. Cell 2019, 30, 1786-1790. [CrossRef]

151. Tapley, E.C.; Starr, D.A. Connecting the nucleus to the cytoskeleton by SUN-KASH bridges across the nuclear envelope. Curr. Opin. Cell Biol. 2013, 25, 57-62. [CrossRef]

152. Herrmann, H.; Aebi, U. Intermediate filaments: Molecular structure, assembly mechanism, and integration into functionally distinct intracellular scaffolds. Annu. Rev. Biochem. 2004, 73, 749-789. [CrossRef] [PubMed]

153. Broers, J.L.; Machiels, B.M.; Kuijpers, H.J.; Smedts, F.; van den Kieboom, R.; Raymond, Y.; Ramaekers, F.C. A- and B-type lamins are differentially expressed in normal human tissues. Histochem. Cell Biol. 1997, 107, 505-517. [CrossRef] [PubMed]

154. Bernis, C.; Forbes, D.J. Analysis of nuclear reconstitution, nuclear envelope assembly, and nuclear pore assembly using Xenopus in vitro assays. Methods Cell Biol. 2014, 122, 165-191. [PubMed] 